\title{
Personality and Fibromyalgia Syndrome
}

\author{
Katrina Malin and Geoffrey O. Littlejohn*
}

Department of Medicine, Monash University, Melbourne, Australia

\begin{abstract}
Objectives: We aimed to review how personality characteristics contribute to the onset, maintenance or modulation of fibromyalgia.

Method: The databases Medline and PsychINFO were examined from 1967 to 2012 to identify studies that investigated associations between fibromyalgia and personality. Search terms included fibromyalgia and personality, trait psychology, characteristics and individual differences.

Results: Numerous studies indicate that patients with fibromyalgia experience psychological distress. Various instruments have been used to evaluate distress and related psychological domains, such as anxiety or depression, in fibromyalgia. In many cases, these same instruments have been used to study personality characteristics in fibromyalgia with a subsequent blurring of cause and effect between personality and psychological distress. In addition, the symptoms of fibromyalgia may change pre-illness personality characteristics themselves. These issues make it difficult to identify specific personality characteristics that might influence the fibromyalgia process. Despite this inherent problem with the methodologies used in the studies that make up this literature review, or perhaps because of it, we found no defined personality profile specific to fibromyalgia. However, many patients with fibromyalgia do show personality characteristics that facilitate psychological responses to stressful situations, such as catastrophising or poor coping techniques, and these in turn associate with mechanisms contributing to fibromyalgia.

Conclusion: No specific fibromyalgia personality is defined but it is proposed that personality is an important filter that modulates a person's response to psychological stressors. Certain personalities may facilitate translation of these stressors to physiological responses driving the fibromyalgia mechanism.
\end{abstract}

Keywords: Fibromyalgia, personality, stress, psychology, instruments.

\section{INTRODUCTION}

Fibromyalgia (fibromyalgia syndrome) is a common musculoskeletal pain syndrome, more frequent in women than men (9:1 respectively) and occurring in up to $2-4 \%$ of the population within Western societies [1]. It is characterized by widespread pain and abnormal tenderness, associated with variable stiffness, fatigue, poor quality sleep, cognitive disturbance and emotional distress [2,3]. Major quality of life issues result and these have high societal impact, including medical, psychological and financial [4].

Clinicians typically recognize certain personality characteristics that they associate with fibromyalgia. For instance, patients with fibromyalgia have been described as perfectionist [5], introspective, demanding [6] and at times exhausting to manage [7]. While such personality traits may appear to contribute to the development and/or persistence of fibromyalgia symptoms, due to the complexities of both personality research and the pathophysiology of fibromyalgia, the links between the two remain unclear.

Personality is generally considered to be an integration of affective, cognitive and behavioural patterns [8], at both a conscious and unconscious level [9] that is unique to a

*Address correspondence to this author at the Monash Rheumatology, Level 3, Block E, Monash Medical Centre, 246 Clayton Road, Clayton, Victoria, 3168, Australia; Tel: (613) 95943565, (613) 95946512;

E-mail: geoff.littlejohn@monash.edu person. The study of personality is not straightforward. Numerous theories and perspectives have been proposed to account for the similarities and differences in human nature that typify personality, particularly how, when and why people adapt within certain environments. The breadth of theories is extensive with no single, unifying approach that captures all the elements of personality. Personality is multifaceted and therefore no simple assessment tool can account for all domains of personality.

This review focuses on the "top-down" model of fibromyalgia mechanisms in order to explore associations between personality and fibromyalgia (Fig. 1). Life predicaments represent events that may trigger psychological responses, including thoughts and emotions. These in turn may modulate biological responses that include pain, tenderness, fatigue, sleep and cognitive changes, components of the fibromyalgia phenotype. Biological pain generators in the musculoskeletal system may provide the substrate for pain amplification in this setting, but this model places psychological factors, in the broad sense of that term, as the primary cause for fibromyalgia. Life events are filtered, or modulated, by factors such as core beliefs, coping skills and control. Personality is also seen as a filter between life events and psychological responses in this model. A number of pervading and variable factors, such as mood change, anger, and stress may contribute to background psychological distress and further amplify this process. Finally, the psychological and biological responses in 
themselves will feedback and cause more psychological distress.

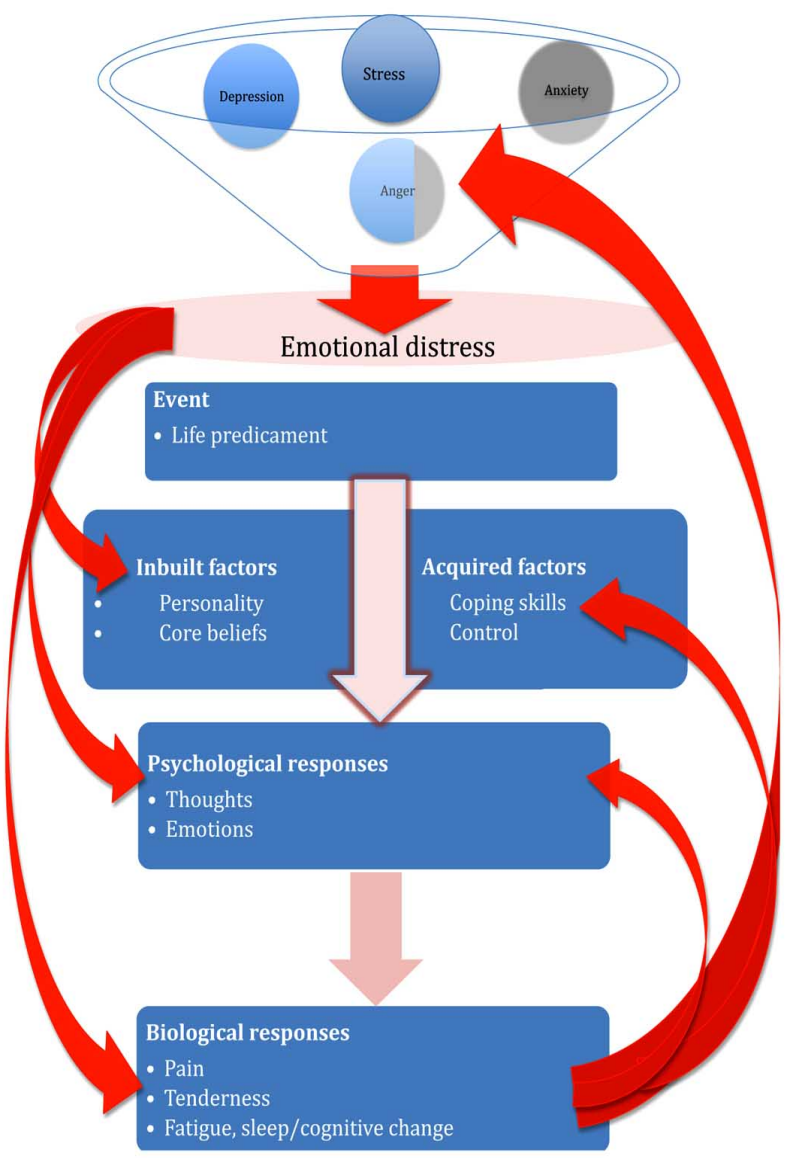

Fig. (1). Proposed model of fibromyalgia linking emotional distress, life events and physical responses. Personality is seen as one of a number of modulators or "filters" of psychological responses that might link to the clinical features of fibromyalgia. Arrows on the left indicate the modulating effect of psychological distress on down-stream responses and arrows on the right indicate "feed-back" effects on distress.

This model fits with the biopsychosocial model of illness in fibromyalgia [10]. Central psychological factors, acting under the influence of external social stressors, result in emotional distress that in turn may activate physiological stress responses if modifying "filters" allow. These filters include the individual's personality, belief system, sleep pattern and other psychosocial influences - each possibly facilitating or impeding this outcome. Change in function of pain-associated brain areas may then allow for pain and related sensory sensitization that in turn, depending on the body "substrate"-musculoskeletal, gastrointestinal, genitourinary, auditory or other- will result in characteristic symptoms and signs of the sensitization process in that organ system [11]. These changes result in the clinical phenotype that is diagnosed as fibromyalgia [12].

The relationship between psychological factors and fibromyalgia clinical features is more complex than this model suggests, as identifying cause and effect is difficult [13]. Psychosocial factors, including personality, may contribute to the initiation of the fibromyalgia mechanism, as discussed above, but they may also modulate the process once established. The subsequent pain, sleep change and fatigue may be further aggravated by pain-associated maladaptive coping techniques and negative pain beliefs [14], each likely influenced by personality. In addition, these responses in themselves may also influence aspects of personality. With such interacting feedback influences on the fibromyalgia process it is therefore a challenge to identify how personality impacts on fibromyalgia $[6,15,16]$. This review presents studies on the personality of fibromyalgia patients and discusses them in the context of current knowledge of the pathophysiology of this condition.

\section{METHODS}

The databases Medline and PsychINFO were examined from 1967 to August 2011 to identify studies that investigated associations between fibromyalgia and personality. Search terms included personality, traits, characteristics, individual differences and fibromyalgia. The terms were combined to elicit the relevant articles, refining the search to include only journal articles, those in English and those that defined personality on a validated scale (Fig. 2). All references pertaining to elicited articles were also reviewed.

\section{RESULTS}

\section{General Personality-Related Descriptors Associated with Fibromyalgia}

Certain personality-related characteristics that may increase emotional distress are noted in individuals with fibromyalgia. These include perfectionism, having unrealistic expectations $[9,17,18]$ and having Type A personality [19]. There may be difficulty in relaxing, increased irritability, decreased social desirability, adoption of a sick role, increased anger and indirect aggression, poor coping techniques [14], pessimistic thinking, anxiety about the future [20], a tendency to somatize $[17,21]$, pedantism, to be in need of order and planning [6], being overly clean [9] and having difficulties in verbally expressing feelings and emotions. Personality disorders are also noted but are not the subject of this review.

\section{Personality Scales in Fibromyalgia}

There is inconsistency and potential confusion in the choice of scales used to identify aspects of personality in fibromyalgia. Individual characteristics that technically are not personality traits, such as depression, anxiety, and psychological distress, are often classified as "personality". These dimensions tend to ascribe styles that reflect constellations of characteristics rather than specific individual traits, but they do in turn have a significant influence on the underlying personality that may be fundamentally important to the fibromyalgia mechanism. For instance, a person with depressive characteristics will report cognitions, emotions and behaviors impeded by this state that in turn influences their choice of internal and external coping mechanisms.

There are many limitations of the specific personality scales/tools to be discussed, ranging from length, biases, cross cultural issues, language considerations and questions surrounding causality. When applied to pain research, 


\begin{tabular}{|c|c|}
\hline \multicolumn{2}{|l|}{ Data bases: PsychINFO and Medline } \\
\hline \multicolumn{2}{|c|}{ Key words: fibromyalgia, personality, traits, individual differences, characteristics } \\
\hline \multicolumn{2}{|l|}{ Medline: } \\
\hline Fibromyalgia & $\mathrm{N}=5314$ \\
\hline Personality, traits, individual differences, characteristics & $\mathrm{N}=1080$ \\
\hline Articles identified using combined search terms & $\mathrm{N}=75$ \\
\hline \multicolumn{2}{|l|}{ PsychINFO: } \\
\hline Fibromyalgia & $\mathrm{N}=1825$ \\
\hline Personality, traits, individual differences, characteristics & $\mathrm{N}=40,000$ \\
\hline Articles identified using combined search terms & $\mathrm{N}=24$ \\
\hline Total articles considered & $\mathrm{N}=99$ \\
\hline \multicolumn{2}{|l|}{ Inclusion criteria: } \\
\hline \multicolumn{2}{|l|}{ Journal article/human/adult/English } \\
\hline \multicolumn{2}{|l|}{ Non-meta-analysis } \\
\hline \multicolumn{2}{|l|}{ Personality defined from personality scale } \\
\hline Studies excluded: & $\mathrm{N}=68$ \\
\hline Total studies reviewed: & $\mathrm{N}=31$ \\
\hline
\end{tabular}

Fig. (2). Methodology of literature review.

specific items on many scales tend to reflect the individual's response to pain rather than to any specific psychopathology causing the problem. It is noted that the fourth edition of the Diagnostic and Statistical Manual of Mental Disorders- TR indicates that to be diagnosed with a pain syndrome psychological factors need to be the cause of pain, rather than a consequence [22]. This distinction is often not clearly defined in studies on fibromyalgia. Most often results from personality tools in these settings reflect influences of nonorganic clinical syndromes and/or outcomes from psychological or medical treatment rather than the intrinsic personality. Currently there are limited studies on personality in the pre-fibromyalgia population, including those that investigate the triggers associated with development of fibromyalgia.

\section{The Minnesota Multiphasic Personality Inventory (MMPI/MMPI 2)}

The MMPI/MMPI 2(shortened version) is the most widely used personality tool comprising 10 personality scales along with 3 validity scales [23]. Developed initially to reflect the levels of psychopathology in a psychiatric population, the MMPI conceptually represents an individual's conscious thought through identification of their psychological abnormalities, and their subsequent ability to adapt to the community [24]. However, some items in the MMPI are intrinsically related to somatic symptoms. This means that within a fibromyalgia population, where somatic symptom reporting is high, there is a resultant artificial elevation of scores [25]. In this setting, in terms of personality influences $[24,26]$ the MMPI highlights characteristics of the illness, such as living with pain, rather than the cause of the illness itself. Report profiles therefore often reflect the differences between groups rather than similarities [27].
It is argued that when the MMPI is used in appropriate circumstances it does reflect the original purpose of the instrument through the identification of the underlying personality structure that can explain the development of the chronic pain condition [28]. This instrument however has been used to investigate various clinical syndromes that lack clear "organic" cause, particularly in order to predict outcomes of medical or psychological interventions [24].

\section{MMPI/MMPI-2 in Fibromyalgia}

When MMPI was first applied to fibromyalgia patients and compared to control groups a number of significant differences were noted [13, 14, 24, 29, 30]. A profile based on the grouping of hysteria, hypochondriasis and depression [14], collectively labeled the "conversion V" profile, is present in fibromyalgia compared to controls [29]. This profile is said to represent the psychological influence on physical symptoms whereby individuals transpose emotional problems into somatic conditions. However living with a chronic painful condition in itself will result in an emotional impact from the pain and that could include depression [31], due to the severity or length of suffering [24], thus casting doubt on this "personality' profile as measuring a causal factor in fibromyalgia. Furthermore, as previously mentioned, items within the scale intrinsically relate to clinical characteristics of many similar chronic "nonorganic" conditions, particularly disturbed sleep, fatigue, distress and pain and so encompass conditions that overlap with fibromyalgia. In short, studies of MMPI in the context of chronic pain suggest that the MMPI result is independent of psychological status [13].

The non-specificity of this profile was also highlighted in a study that found the conversion $\mathrm{V}$ profile both in fibromyalgia and chronic pain patients but not in rheumatoid arthritis or healthy controls, with no significant difference between chronic pain or fibromyalgia groups $[24,32]$. The 
conversion "V" profile is not stable over time [30]. A study utilizing a "mini-MMPI", the MMPI-2, reported that psychological disturbance in fibromyalgia changed with pain intensity and found neurotic symptoms common in all groups [24]. Against this background, a study of 31 fibromyalgia patients compared to 31 controls found that the responses on the MMPI lacked any significant psychopathology, with many scales recording "normal levels" indicating that the MMPI showed "no psychological disturbance of any serious nature" [33]. A further study reported correlation between previous psychiatric treatment and higher levels of somatic complaints in fibromyalgia, however all individuals in this study were involved in litigation which may skew the degree of psychopathology reported [34].

In an attempt to improve the usefulness of the scale contemporary normative data, derived from the original norms, has been defined. Groups were statistically recalculated to separate a normal (healthy) group, a chronic pain group and a psychologically disturbed group [13, 29, 35]. These studies reported that less than one-third of fibromyalgia patients could be categorized into the psychologically disturbed group with $41 \%$ normal and $47 \%$ having the chronic pain profile. The lack of correlation between the key triad features of pain, sleep, and fatigue and the MMPI scales was the explanation for these findings [13].

At best, using the MMPI/2, psychological issues are implied in many fibromyalgia patients but at worst the nature and exact placement of the psychological change in the topdown fibromyalgia cascade is not possible (Fig. 1).

\section{Cesarec Marke Personality Schedule (CMPS)}

This Swedish scale, derived by factor analysis, is based on Murray's theory of needs. This theory identifies the motives an individual requires to drive their desired outcomes. The "needs" reflect aggression, extraversion and neuroticism. Underlying this theory of personality is the existence of two main needs: primary needs of hunger, thirst and sexuality and secondary needs of wishes and pursuits. The motivation for the need reflects the individuals' push to achieve certain outcomes. Traits are seen as either stable or unstable with personality reflected as maturity due to historical, cultural and social components [36].

\section{CMPS in Fibromyalgia}

A study, aimed to validate a computer based version of the CMPS in 110 fibromyalgia patients in comparison to a pen - paper version in 45 separate fibromyalgia patients and compared to a normative group, found that this scale indicated a greater need for order in the fibromyalgia groups [9]. This identified the fibromyalgia patient to be pedantic, perfectionist, or in need of order and/or planning, in response to everyday stressors. These are all attributes that are evident in clinical practice.

\section{Karolinska Scales of Personality (KSP)}

The KSP scale is hypothesized to reflect temperament dimensions that underlie the biological disposition and as such the relationship that temperament plays on the development of personality. KSP is said to be a measure of stable traits contributing to personality rather than a level of psychopathology. It is not designed to assess the "whole personality" but rather to explore dimensions that contribute to the person, specifically that of anxiety proneness, impulsivity and aggression. The scale is argued to "handle different types of pain easier" [37] and is a closer fit to the proposed fibromyalgia top down model with the scale delineating an individual's response to psychological stressors. These dimensions of the KSP are said to explain the individual's vulnerability towards certain forms of psychopathology but not the psychopathology itself. Psychometrically, the scale shows validity and it is less time consuming, easier to apply and interpret than the MMPI/2 [37]. Factor studies compared the KSP to both the 3 factor and 4 factor Eysenck Personality Inventory (EPI) (see later) and found consistency amongst a number of traits of the KSP to EPQ such as neuroticism to negative emotionality [38]. Limited studies compare the KSP to the MMPI-2.

\section{KSP in Fibromyalgia}

This instrument shows that fibromyalgia individuals who rate high on muscle tension are influenced by their personality traits $[20,37]$. In a study, comparing 73 fibromyalgia patients and 200 controls, fibromyalgia patients reported significantly higher somatic anxiety (autonomic disturbance, distress and panic attacks), muscular tension and psychasthenia (fatigue). However it has been suggested that this was due to reduced energy due to pain, fatigue and sleep deprivation, all common components of fibromyalgia. The KSP instrument does identify personality traits that may contribute to the process of central sensitization, such as heightened anxiety, pronounced preoccupation with somatic complaints, consequent inability to relax and constant levels of fatigue [37].

\section{Temperament and Character Inventory [39]}

The TCI reviews different dimensions of temperament and character constructed from biological, social, psychological and cultural factors [40]. Temperament (likely an inherited quality) is sub-classified into novelty seeking, harm avoidance, reward dependence, and persistence. Character (a more transient quality), produces a sense of self directedness (will power and determination), cooperativeness (tolerance and empathy) and self transcendence (spirituality) $[36,41]$. The temperament and character dimensions are said to be mutually exclusive with the inventory measuring both normal and abnormal behaviour [42, 43]. From a psychobiological perspective the hypothesis argues that neurochemical transmitters determine the stimulus response patterns and, it is these patterns that shape personality. Underlying temperament are the neurochemical transmitters, serotonin (the inhibition system), dopamine (the activation system) and noradrenalin (the behavioural maintenance system). These factors affect the modulating pain pathways i.e. the inhibitory modulation of the descending pathways that are important in chronic pain [42].

\section{TCI in Fibromyalgia}

Using this instrument, 40 fibromyalgia patients, when compared to 38 healthy controls, were found to have a significantly high level of harm avoidance [40]. It was speculated that fibromyalgia individuals present with a personality style that reflects being easily worried, 
pessimistic about their future, having heightened fear and avoidance of situations with which they cannot cope [40]. Interestingly, harm avoidance also corresponds to the KSP findings of heightened levels of anxiety, tension and fatigue [37], giving further support to this personality style in fibromyalgia. In another study, fibromyalgia individuals were found to struggle with self-directedness [44], which raises questions around their ability to take control in regards to the self. However other studies were inconclusive regarding the findings in fibromyalgia [40]. Using this instrument personality traits do associate with the development of fibromyalgia, but whether this is cause or effect cannot be answered by these studies. For example, the development of harm avoidance may be a result of long-term exposure to fibromyalgia and not a precursor of the condition.

\section{Tridimensional Personality Questionnaire [TPQ]}

The TPQ is derived from social and biological perspectives of personality. It is argued that personality development is formed though the interaction of the individual's genetic disposition on their environmental domains [45-47]. Based on a grand unifying theory, this personality scale focuses on the multidimensional temperament traits of novelty seeking, harm avoidance and reward dependence [48].

\section{TPQ in Fibromyalgia}

In a study using the TPQ, 81 fibromyalgia patients compared to 458 controls showed a linkage between the serotonin transporter gene and anxiety-prone personality traits (high harm, low novelty profile) $[49,50]$. An exclusive fibromyalgia profile that significantly differed from the controls was identified. Additionally, the frequency of the dopamine receptor D4 (DRD4) was decreased significantly in the fibromyalgia group compared to controls, with the DRD4 also correlating with low novelty seeking on the TPQ. This suggests that both serotonin and dopaminergic neurotransmission are involved in fibromyalgia pain mechanisms and personality characteristics may be involved in this association [50].

\section{Sociotropy and Autonomy Scale (SAS)}

The SAS measures two distinct cognitive traits, namely sociotropy and autonomy [51]. Sociotropy is said to be the need of the individual to gain approval from others where as autonomy is the individual's capacity to rely on their own abilities. The SAS scale has been used in past studies related to major mood disturbances. It has shown links between the underlying beliefs structure and distorted cognitions to mood disturbances, particularly depression.

\section{$S A S$ in Fibromyalgia}

In a study utilizing the SAS, the personality style underlying major depression disorder and fibromyalgia were found to be quite different. When individuals with fibromyalgia also had depressive symptoms, these were felt to be a consequence to the condition rather than due to their underling personality [28].
The NEO Five-Factor Personality Inventory (NEO PI-R, Big 5)

The NEO PI-R inventory measures 5 broad dimensions of personality, namely neuroticism, extraversion, agreeableness, conscientiousness and introversion [52]. The scale is said to identify "differences among normal individuals" by identifying how a person may feel, think and act. The traits are said to stable throughout adult life, unless there is a conscious decision or major life event that produces major change [53]. Neuroticism has been extensively investigated in relation to survival needs [54] coping and, optimism [49], health practices and number of physical symptoms [53, 55]. It has received extensive notoriety with the predominant focus being on the relationship between neuroticism and symptom perception and report bias [56].

Neuroticism is the most explored personality trait in pain research and has been suggested to associate with the unpleasantness of the pain, and pain threshold rather than with the pain intensity. The degree of neuroticism will impact on psychological factors such as perceived stress and social support [57]. Extroversion characteristics denote an individual who actively interacts with a stimulus, has an outgoing nature and associates with better health outcomes. In contrast, introversion characteristics include increased cortical arousal, lower threshold for sensory stimulus and more physiological reactivity to stressors.

\section{NEO PI-R in Fibromyalgia}

There are few studies using the NEO PI-R questionnaire in fibromyalgia. In one study, there were inconsistent findings in regards to the influence of neuroticism on pain sensitivity between a fibromyalgia group, who sort medical treatment, compared to another fibromyalgia group, who sort no medical treatment [58]. In another study, neuroticism was examined in terms of being a possible underling trigger to the development of fibromyalgia. It was suggested that the fibromyalgia individual's inability to adapt due to their high pain sensitivity and low pain threshold resulting in maintenance of pain. The influence of neuroticism on pain recall did not show that interference with recall was impaired through recall bias of memory, retrieval and interpretation of painful events. However, studies in fibromyalgia are more limited and conflicting and they have tended to focus on neuroticism and extraversion. These traits have been used based on associations between them and outcomes associated with illness behaviour. It is also suggested that neuroticism has the potential to predict physical health outcomes [59]. Some studies have suggested that fibromyalgia is a substrate of neuroticism [60], while others have reported a lack of reliability in the predictive power of neuroticism over external psychosocial factors [58] and then while neuroticism was found to influence pain recall, there were no associations to the accuracy of recall nor pain intensity or ratings of unpleasantness of pain [61]

\section{The Eysenck Personality Inventory [EPI]}

The EPQ uses polarized continuous variables underlying trait personality to cover the "whole field of personality" 
[38] with the main dimensions being psychoticism (tough mindedness), extraversion and neuroticism (defined as reactivity/emotional instability with the inability to adapt) $[38,60,62]$.

\section{EPI in Fibromyalgia}

The EPI shows high scores in the fibromyalgia population. The fibromyalgia individual is said to be anxious, worried, depressed, and a poor sleeper. A study, using a biopsychosocial approach explored how best to explain the pain variances found within a fibromyalgia population allowed for numerous factors that might shape and maintain fibromyalgia symptoms. Neuroticism, along with stress, was reported as having good predictive power in a sample that compared 22 fibromyalgia patients to 17 controls. Forty-one percent of the variance was explained by personality (neuroticism) and stress, along with factors associated with the hypothalamic-pituitary-adrenal axis and to the autonomic nervous system [63].

\section{Other Personality Characteristics}

\section{Perfectionism and Type A in Fibromyalgia}

In defining the personality characteristics of an individual with fibromyalgia there are other elements, which are not truly defined as personality traits yet depict important descriptors of their behaviour, that also need to be mentioned. Clinical observations have noted the person with fibromyalgia be perfectionist, pedantic, an over achiever, and a "go getter". As such perfectionism and type A behaviour are potential characteristics that may contribute to fibromyalgia. Both elements have been associated with poor health. While studies are limited, a few have shown an overactive lifestyle, along with negative perfectionism and Type A behaviour, are potential elements in developing and maintaining fibromyalgia. It was suggested that these individuals would "burn out" due to self-perpetual behaviors that included exhaustion from exacerbating distress, leading on to greater fatigue. This in turn meant that their higher expectations were not achieved, triggering further stress and in turn producing negative self-beliefs, reinforcing a sense of helplessness. There is a significant positive relationship between perfectionism and Type A, particularly in regard to impatience, competitiveness and socially perceived and imposed standards [64].

Another study into Type A characteristics and perfectionism within the fibromyalgia population found that those high in sense of coherence reported less Type A behaviour. However, as Type A was used as a constant [19] for both the fibromyalgia and control groups, limited explanations can be extrapolated.

Table 1 summarizes selected studies that relate to aspects of personality in patients with fibromyalgia.

\section{DISCUSSION}

Chronic pain incorporates a complex mix of nociception, peripheral neural processing, cognitive processing, and affective and behavioural responses. Early studies investigating the relationship between personality and pain (not identified as fibromyalgia-related) recognized various factors, both physiological and psychological, that made an individual more vulnerable to pain. More recent work has also focused on how personality might influence the way individuals with certain characteristics adjust to pain. For instance, there may be resultant negative attitudes and expectations that inhibit improvement. Personality therefore might be involved in various aspects of chronic pain, as seen in fibromyalgia, and be involved in triggering, maintaining and exacerbation of the fibromyalgia process.

It is noted that while personality appears to be intricately related to pain experience, this review of the fibromyalgia literature shows that less than $3 \%$ of the total articles in these selected data bases on fibromyalgia have attempted to investigate the relationship between personality based individual differences and fibromyalgia.

It is often unclear whether the personality elements result from or cause symptoms associated with fibromyalgia. In some studies it has been noted that the trait tests and inventories used to assess personality may not be pain state independent [78]. Many trait scores improve with treatment and hence cross-sectional studies done in a population that already has the pain and other significant health issues of fibromyalgia may not reflect pre-illness personality accurately. We did not find it possible to assess this issue further in our review due to limited clinical description of the patients deemed to have fibromyalgia. We have assumed that all patients in the reviewed studies had symptomatic fibromyalgia. Thus it is difficult to describe an "at-risk" personality in this context.

To aid assessment of personality in fibromyalgia for this review we have approached fibromyalgia in the context of a "top down" model. Personality characteristics are proposed as important mediators in the clinical picture of FM. The conceptual premise of the top down model integrates the central sensitization process of pain-related neural pathways as the end-result of centrally acting biopsychosocial inputs. This forms the framework that enables the establishment of bidirectional brain-body pathways [79]. Psychosocial factors, including personality, are seen as modulating factors in this model. Different personality styles may either enhance or inhibit the translation of life predicaments into bio-emotive outputs.

This review explores the literature examining the influence of personality in fibromyalgia. From the outset it is apparent that there is lack of clarity in the data partly relating to the precise definition of personality and partly relating to the nature of fibromyalgia itself. Theories of personality are diverse and complex, often overlapping, with no universally accepted grand theory. On the other hand a mix of biopsychosocial components many of which interact with aspects of personality characterizes fibromyalgia. The literature is therefore limited by these differences in instrument design and also by the limited data on clinical aspects of the patients with fibromyalgia. Some of the literature dates to a time when generic "personality" instruments such as the MMPI were used, while other instruments use approaches that include genetic aspects of personality. Additionally there may be bias in patient selection from large tertiary centers where patients may have more severe illness characteristics that may distort both physical and psychological characteristics [80]. It is difficult to comment on the direction and magnitude of these potential biases due to insufficient data of the patient cohorts. 
Table 1. Selected Studies that Relate to Aspects of Personality in Patients with Fibromyalgia

\begin{tabular}{|c|c|c|c|c|c|}
\hline Author & Date & Population & Personality Scale & Construct Investigated & Comment \\
\hline \multicolumn{6}{|c|}{ MMPI: Minnesota Multiphasic Personality Inventory } \\
\hline $\begin{array}{l}\text { Payne T, Leavitt F, Garron } \\
\text { D et al. [30] }\end{array}$ & 1982 & $\begin{array}{l}\text { FM } 30 \\
\text { RA } 30 \\
\text { OA } 30\end{array}$ & MMPI & $\begin{array}{l}\text { Personality differences and levels } \\
\text { of psychopathology }\end{array}$ & $\begin{array}{l}\text { Concluded that FM individual's } \\
\text { psychological state is not directly due to } \\
\text { pain or their disability; that their } \\
\text { psychological status is variable and } \\
\text { contributes significantly to the symptoms } \\
\text { that they experience. }\end{array}$ \\
\hline $\begin{array}{l}\text { Wolfe F, Cathey MA, } \\
\text { Kleinheksel SM et al. [65] }\end{array}$ & 1984 & $\begin{array}{l}\text { FM } 46 \\
\text { RA } 32 \\
\text { RA no FM } 43\end{array}$ & MMPI & $\begin{array}{l}\text { Psychological factors that } \\
\text { contribute to psychopathology }\end{array}$ & $\begin{array}{l}\text { Just over } 25 \% \text { of FM patients had "normal } \\
\text { profile" compared to over } 50 \% \text { of controls; } \\
\text { FM patients report significant psychopathic, } \\
\text { psychasthenia and paranoia scales along } \\
\text { with significant anxiety and depression } \\
\text { scales }\end{array}$ \\
\hline $\begin{array}{l}\text { Ahles T, Yunus M, Gaulier } \\
\text { B, Riley S, Masi A [35] }\end{array}$ & 1986 & $\begin{array}{l}\text { FM } 45 \\
\text { RA } 30 \\
\text { NC } 32\end{array}$ & MMPI & $\begin{array}{l}\text { Psychological factors that } \\
\text { contribute to psychopathology }\end{array}$ & $\begin{array}{l}\text { Low psychopathology found in FM, even } \\
\text { though similar patterns were obtained when } \\
\text { recalculating groups based on new } \\
\text { contemporary norms. Raises suggestions } \\
\text { that using previous norms may reflect } \\
\text { findings based on living with a chronic } \\
\text { condition, directly or indirectly, rather than } \\
\text { actual psychopathology. }\end{array}$ \\
\hline $\begin{array}{l}\text { Yunus MB, Ahles TA, } \\
\text { Aldag JC, Masi A [13] }\end{array}$ & 1991 & FM 103 & MMPI & $\begin{array}{l}\text { Psychological factors that } \\
\text { contribute to psychopathology }\end{array}$ & $\begin{array}{l}\text { MMPI divided group into } 3 \text { categories, } \\
\text { symptoms don't confound outcomes of the } \\
\text { MMPI, with exception of pain severity that } \\
\text { was influenced by psychological factors. }\end{array}$ \\
\hline $\begin{array}{l}\text { Herken H, Gursoy S, Yetkin } \\
\text { OE, Virit O, Esgi K [5] }\end{array}$ & 2001 & $\begin{array}{l}\text { FM } 48 \\
\text { NC } 48\end{array}$ & MMPI & $\begin{array}{l}\text { Personality characteristics and } \\
\text { depression levels }\end{array}$ & $\begin{array}{l}\text { Patients reported high levels of anxiety and } \\
\text { poor ability to cope with stress, leading to } \\
\text { somatizing. }\end{array}$ \\
\hline Ardic F, Toraman F [4] & 2002 & $\begin{array}{l}\text { FM } 45 \\
\text { CP } 40 \\
\text { RA } 20 \\
\text { NC } 20\end{array}$ & MMPI/2 & Psychological dimensions & $\begin{array}{l}\text { Neurotic symptoms identified in pain } \\
\text { conditions unlike control; psychological } \\
\text { disturbance alters with pain duration. }\end{array}$ \\
\hline Gerson A, Fox D [32] & 2003 & $\begin{array}{l}\text { FM } 19 \\
\text { CP } 19 \\
\text { All litigating }\end{array}$ & MMPI 2 & $\begin{array}{l}\text { Personality variables in FM } \\
\text { reviewed to the level of psychiatric } \\
\text { disorder }\end{array}$ & $\begin{array}{l}\text { Psychopathology not uniquely different } \\
\text { between groups, outcomes potentially } \\
\text { influenced by litigation, FM had greater } \\
\text { somatic pre-occupation, more likely to have } \\
\text { past psychiatric treatment. }\end{array}$ \\
\hline Rains JC, Penzien DB [66] & 2003 & $\begin{array}{l}\text { CP } 21 \text { (FM 18) } \\
\text { Psychiatric } 15 \\
\text { Medical } 18\end{array}$ & MMPI & $\begin{array}{l}\text { Psychological relationships } \\
\text { explored }\end{array}$ & $\begin{array}{l}\text { CP group reported higher on } \\
\text { hypochondriasis and hysteria and slightly } \\
\text { lower on depression scales than the } \\
\text { psychiatric group. CP exhibited pain profile } \\
\text { suggesting that psychological distress } \\
\text { relates to somatic complaints. }\end{array}$ \\
\hline $\begin{array}{l}\text { Blasco Claros L, Mallo Cano } \\
\text { M, Mencia Presa M, et al. } \\
\text { [67] }\end{array}$ & 2006 & $\begin{array}{l}\text { FM } 75 \\
\text { NC } 55\end{array}$ & MMPI/2 & $\begin{array}{l}\text { Differing profiles based on } \\
\text { personality disorders/personality } \\
\text { psychopathology }\end{array}$ & $\begin{array}{l}\text { Two different psychopathological patterns, } \\
\text { identified from Bradley's classification } \\
\text { from the MMPI-2 in FM, provide a new } \\
\text { measure that discriminates the severity of } \\
\text { FM symptoms. }\end{array}$ \\
\hline $\begin{array}{l}\text { Johnson A, L, Storzbach D, } \\
\text { Binder LM, et al. [68] }\end{array}$ & 2010 & $\begin{array}{l}\text { FM } 49 \\
\text { Non epileptic } \\
\text { seizure } 49 \\
\text { Epileptic seizure } \\
49 \\
\text { NC } 49 \\
\text { All Gulf war } \\
\text { veterans }\end{array}$ & MMPI 2 & $\begin{array}{l}\text { Personality differences were } \\
\text { studied between those with a } \\
\text { somatic disorder compared to } \\
\text { individuals with a physical illness. }\end{array}$ & $\begin{array}{l}\text { The FM individuals reported higher } \\
\text { hypochondriasis and hysteria scales than the } \\
\text { epileptic and NC. The non epileptic seizure } \\
\text { and FM similar in the hysteria scale (both } \\
\text { said to be "medically unexplained" } \\
\text { conditions) }\end{array}$ \\
\hline
\end{tabular}


(Table 1) contd.....

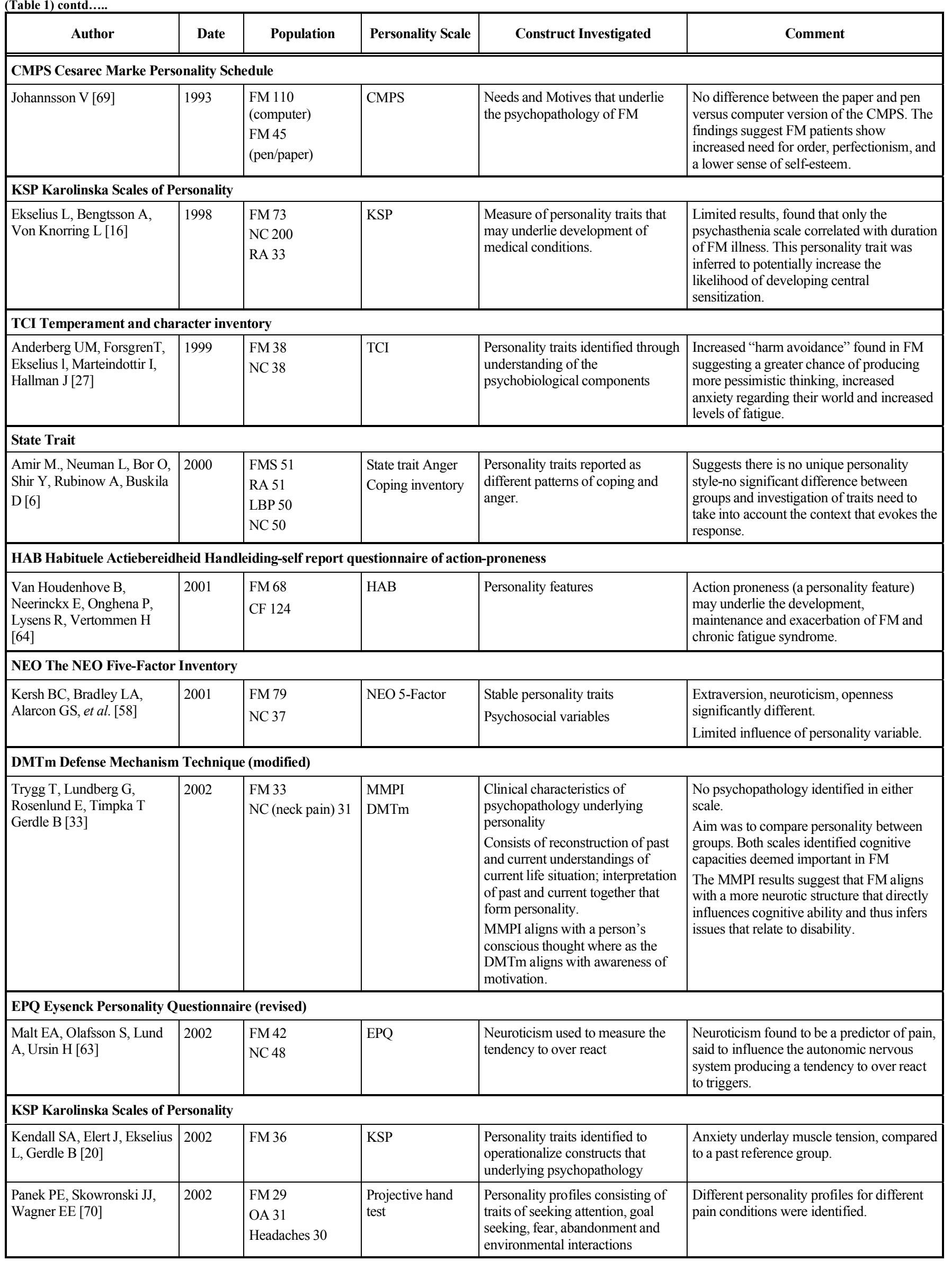


(Table 1) contd.....

\begin{tabular}{|c|c|c|c|c|c|}
\hline Author & Date & Population & Personality Scale & Construct Investigated & Comment \\
\hline \multicolumn{6}{|c|}{ Eysenck Personality Inventory } \\
\hline $\begin{array}{l}\text { Ramirez-Maestre C, Lopez } \\
\text { Martinez A E, Zarazaga, R E } \\
{[71]}\end{array}$ & 2004 & $\begin{array}{l}\text { FM } 14 \\
\text { OA } 22 \\
\text { Arthrosis } 21 \\
\text { Cancer } 13 \\
\text { Lumbago } 9 \\
\text { OP } 8 \\
\text { Neuralgia } 4 \\
\text { Hernia } 3 \\
\text { Trauma } 2\end{array}$ & $\begin{array}{l}\text { Eysenck } \\
\text { personality } \\
\text { Inventory }\end{array}$ & $\begin{array}{l}\text { Neuroticism and extraversion } \\
\text { explored }\end{array}$ & $\begin{array}{l}\text { Individual pain experiences were not } \\
\text { explored, overall neuroticism positively } \\
\text { correlated to passive coping, extraversion } \\
\text { partially correlated positively to active } \\
\text { coping techniques. }\end{array}$ \\
\hline \multicolumn{6}{|c|}{ TPQ Tridimensional Personality Questionnaire } \\
\hline $\begin{array}{l}\text { Buskila D, Cohen H, } \\
\text { Neumann L, Ebstein RP [50] }\end{array}$ & 2004 & $\begin{array}{l}\text { FM } 81 \\
\text { NC } 458\end{array}$ & TPQ & $\begin{array}{l}\text { Personality domains [Harm } \\
\text { Avoidance/Novelty seeking] linked } \\
\text { to genetics of three main } \\
\text { neurotransmitters. }\end{array}$ & $\begin{array}{l}\text { FM mechanisms (neurotransmitters) } \\
\text { associated with personality traits }\end{array}$ \\
\hline $\begin{array}{l}\text { Glazer Y, Buskila D, } \\
\text { Cohen H, Ebstein R P } \\
\text { Neumann L [72] }\end{array}$ & 2010 & $\begin{array}{l}\text { FM } 129 \\
\text { Undiagnosed } \\
\text { relatives with FM } \\
27 \\
\text { NC } 30\end{array}$ & TPQ & $\begin{array}{l}\text { Genetic links to personality } \\
\text { (temperament) traits, exploration of } \\
\text { three neurotransmitters associated } \\
\text { with activation (novelty seeking), } \\
\text { inhibition (fear avoidance) and } \\
\text { maintenance (reward) }\end{array}$ & $\begin{array}{l}\text { Findings suggest that there are similarities } \\
\text { within first generation families of FM } \\
\text { individuals, suggesting a hereditary } \\
\text { component. }\end{array}$ \\
\hline \multicolumn{6}{|c|}{ The Big Five Personality Inventory } \\
\hline $\begin{array}{l}\text { Zautra A, Johnson L, Davis } \\
\text { M [73] }\end{array}$ & 2005 & $\begin{array}{l}\text { FM } 86 \\
\text { OA } 38\end{array}$ & The Big Five & $\begin{array}{l}\text { The degree of neuroticism } \\
\text { displayed by the sample population }\end{array}$ & $\begin{array}{l}\text { The FM group displayed higher neurotic } \\
\text { traits than the OA group; development of } \\
\text { chronic pain linked to lack of resilience, } \\
\text { stated as a lack of positive emotional } \\
\text { resources rather than increased negative } \\
\text { affect. Neuroticism is challenged as basis } \\
\text { for emotional difficulties. }\end{array}$ \\
\hline Malin K, Littlejohn G O [74] & 2011 & $\begin{array}{l}\text { FM } 27 \\
\text { NC } 29\end{array}$ & The Big Five & $\begin{array}{l}\text { Associations between personality } \\
\text { traits, psychological variables and } \\
\text { clinical features explored. }\end{array}$ & $\begin{array}{l}\text { Neuroticism trait in females with FM under } \\
\text { age } 39 \text { significantly linked to clinical } \\
\text { features, psychological co-morbidities and } \\
\text { stress }\end{array}$ \\
\hline \multicolumn{6}{|c|}{ NEO-PI The NEO Personality Inventory/Revised } \\
\hline Raselli C, Broderick J [61] & 2007 & $\begin{array}{l}\text { FM } 44 \\
\text { OA } 27 \\
\text { RA } 5 \\
\text { AS } 5\end{array}$ & NEO-PI & Neuroticism levels & $\begin{array}{l}\text { Neuroticism was found only to influence } \\
\text { rating the change in pain, not accuracy, } \\
\text { recall or memory. }\end{array}$ \\
\hline \multicolumn{6}{|c|}{ SAS Sociotropy and Autonomy Scale } \\
\hline Nordahl H, Stiles T [28] & 2007 & $\begin{array}{l}\text { FM } 44 \\
\text { MDD } 43 \\
\text { NC } 41\end{array}$ & SAS & $\begin{array}{l}\text { Personality Style based on } \\
\text { cognitive traits }\end{array}$ & $\begin{array}{l}\text { Personality style was related to depressive } \\
\text { mood but not to FM. FM individuals had a } \\
\text { higher sociotropic personality style that } \\
\text { differed significantly from NC. FM without } \\
\text { past MDD reported style similar to NC. }\end{array}$ \\
\hline \multicolumn{6}{|c|}{ TCI-R Temperament and character inventory } \\
\hline $\begin{array}{l}\text { Lundberg G, Anderberg U, } \\
\text { Gerdle B [43] }\end{array}$ & 2009 & $\begin{array}{l}\text { FM } 191 \\
\text { NC } 652\end{array}$ & TCI-R & $\begin{array}{l}\text { Differences in temperament and } \\
\text { character }\end{array}$ & $\begin{array}{l}\text { Independent personality patterns were } \\
\text { established between FM and NC triggered } \\
\text { by the (in) ability to cope with stress. } \\
\text { Character and temperament in FM high in } \\
\text { harm avoidance, persistence and low in } \\
\text { self-directedness. }\end{array}$ \\
\hline $\begin{array}{l}\text { Verdejo-Garcia A, Lopez- } \\
\text { Torrecillas F, Clandre E, } \\
\text { Delgado-Rodriguez A, } \\
\text { Bechara, A [75] }\end{array}$ & 2009 & $\begin{array}{l}\text { FM } 36 \\
\text { NC } 36\end{array}$ & TCI-R & $\begin{array}{l}\text { Personality measures and } \\
\text { relationship to cognitive } \\
\text { functioning }\end{array}$ & $\begin{array}{l}\text { Suggest a mild correlation between } \\
\text { personality traits (persistence and reward } \\
\text { dependence) and cognitive performance. }\end{array}$ \\
\hline
\end{tabular}


(Table 1) contd.....

\begin{tabular}{|c|c|c|c|c|c|c|}
\hline & Author & Date & Population & Personality Scale & Construct Investigated & Comment \\
\hline \multicolumn{2}{|c|}{$\begin{array}{l}\text { Mazza M, Mazza O, } \\
\text { Pomponi M, Nicola M } \\
\text { Padua L, Vicini M, et al. } \\
{[76]}\end{array}$} & 2009 & $\begin{array}{l}\text { FM } 60 \\
\text { NC } 80\end{array}$ & TCI-R & $\begin{array}{l}\text { Temperament and Character } \\
\text { profiles }\end{array}$ & $\begin{array}{l}\text { Results indicated a potential altered sensory } \\
\text { input influencing central sensitization } \\
\text { through the SSRI response and the } \\
\text { personality profiles used. Has the potential } \\
\text { to identify FM individuals who would } \\
\text { benefit from treatment. }\end{array}$ \\
\hline \multicolumn{2}{|c|}{$\begin{array}{l}\text { Riva R, Mork PJ, Westgaard } \\
\text { RH, Ro M, Lundberg U [77] }\end{array}$} & 2010 & $\begin{array}{l}\text { FM } 29 \\
\text { NC } 29\end{array}$ & $\begin{array}{l}\mathrm{KSP} \\
\mathrm{EPQ}(\mathrm{r})\end{array}$ & $\begin{array}{l}\text { To measure stable personality } \\
\text { traits, three subscales used inability } \\
\text { to relax, worrying and feeling } \\
\text { anxious and autonomous } \\
\text { disturbance and links to being over } \\
\text { or under responsive. }\end{array}$ & $\begin{array}{l}\text { FM had increased psychological } \\
\text { characteristics that included higher levels of } \\
\text { neuroticism, and more subjective } \\
\text { physiological complaints, both somatic and } \\
\text { psychological, in comparison to NC }\end{array}$ \\
\hline \multicolumn{7}{|c|}{ Key to abbreviations: } \\
\hline $\mathrm{CF}$ & \multicolumn{6}{|c|}{ Chronic fatigue } \\
\hline CMPS & \multicolumn{6}{|c|}{ Cesarec Marke Personality Schedule } \\
\hline $\mathrm{CP}$ & \multicolumn{6}{|c|}{ Chronic pain } \\
\hline DMTm & \multicolumn{6}{|c|}{ Defense Mechanism Technique (modified) } \\
\hline EPQ (r) & \multicolumn{6}{|c|}{ Eysenck Personality Questionnaire (revised) } \\
\hline FM & \multicolumn{6}{|c|}{ Fibromyalgia } \\
\hline HAB & \multicolumn{6}{|c|}{ Habituele Actiebereidheid Handleiding-self report questionnaire of action-proneness } \\
\hline KSP & \multicolumn{6}{|c|}{ Karolinska Scales of Personality } \\
\hline LBP & \multicolumn{6}{|c|}{ Low back pain $M$} \\
\hline MDD & \multicolumn{6}{|c|}{ Major depressive disorder } \\
\hline MMPI & \multicolumn{6}{|c|}{ Minnesota Multiphasic Personality Inventory } \\
\hline & \multicolumn{6}{|c|}{ Normal controls } \\
\hline NEO-FFI & \multicolumn{6}{|c|}{ The NEO Five-Factor Inventory } \\
\hline NEO PI/R & \multicolumn{6}{|c|}{ The NEO Personality Inventory/Revised } \\
\hline & \multicolumn{6}{|c|}{ Osteoarthritis } \\
\hline RA & \multicolumn{6}{|c|}{ Rheumatoid arthritis. } \\
\hline SAS & \multicolumn{6}{|c|}{ Sociotropy and Autonomy Scale } \\
\hline TCI & \multicolumn{6}{|c|}{ Temperament and character inventory } \\
\hline TPQ & \multicolumn{6}{|c|}{ Tridimensional Personality Questionnaire } \\
\hline
\end{tabular}

A number of psychosocial factors are reported in fibromyalgia [81, 82], ranging from previous traumatic/distressing life events [83-87], psychiatric illness [88], somatization syndromes [89], sleep disturbance [90-92], compensation effects [89], perceptions of disability [93], individual beliefs and poor coping mechanisms, amongst others. Although fibromyalgia can arise for no apparent reason it is often triggered by traumatic events, or even by an accumulation of everyday life hassles [94]. Background stress and response to stress are common themes in fibromyalgia. Descriptors of fibromyalgia patients indicate that there is increased attentiveness, excessive watchfulness and more demand towards their somatic functions. They tend to be more vulnerable to additional stressors and endeavor to control their life circumstances despite an underlying level of anxiety. Aspects of personality that interact with stress thus seem important to fibromyalgia.

Studies into personality have been approached from a variety of theoretical perspectives aiming to best define the differences and similarities of human nature. Traits are considered permanent, continuous and stable characteristics, exhibited in all aspects of social and personal contexts, which influence behavior. In contrast, states are characteristics that are transient, short lived and unstable and are triggered by the individuals' needs, wants and desires. Thus traits denote basic and distinctive behavioral patterns while states, such as responses to varying situational and environmental factors, further modulate the person's innate behavioral style [95].

One approach to defining traits is the "big 5" classification that defines five distinctive groups (neuroticism, extraversion, agreeableness, conscientiousness, introversion) organized through the collection of statistically different defined characteristics [96, 97]. Other approaches to personality include defining specific types of personality style, such as Type A or alexithymia, a theoretical disposition, such as Murray's needs [98], a biological disposition such as temperament (including character) [99], and psychobiological approaches [41].

It is evident that each instrument used to measure elements of personality in fibromyalgia will capture overlapping aspects of a more complex domain and components of one scale will map onto those of another. For instance, elements of neuroticism are seen in the MMPI, Big 5, the Eysenck Personality Inventory as well as others. Each inventory is also based on different theories of personality and thus the measures reflect these differences.

This review has found no studies to suggest that individuals with the FM phenotype have a consistent personality profile. However, limited studies have shown that individuals with FM do have personality dispositions and/or characteristics that are different to those with other defined pain conditions [50, 100]. For instance, combinations of neuroticism and extraversion, elements of perfectionism, and Type A, among others, are all identified in the fibromyalgia population.

In general, the experience of pain is said to be dependent on personality [101], with distinctive patterns of behaviors, thoughts and emotions shaping a person's response to pain. In the case of fibromyalgia the clinical features are thought to relate to the process of central sensitization in the painrelated nervous system whereby otherwise innocuous musculoskeletal sensory inputs translate into pain [102]. The cause of this aberrant neurophysiological mechanism is 
complex but it likely relates to changes in central control pathways connecting the brain to the spinal cord [103]. Emotional distress is commonly described in fibromyalgia [104] and distress in turn has been linked to certain personality traits [79]. Different components of personality may modulate the process underlying central sensitization through influence on these pain-modulating mechanisms such as the stress response and other down stream systems. It has been suggested that personality traits together with central sensitization are the most important factors in individuals developing and also maintaining fibromyalgia [16].

The fact that personality styles and types that promote or amplify emotional distress are more common in fibromyalgia favors this point of view. For example, neuroticism is more common with its associated negative responses to life predicaments and subsequent easy generation of emotional distress. This response is further dependent on the interpretation and coping styles of the individual [105].

While some personality scales identify fibromyalgia patients as being vulnerable to stress other scales have shown links to biological mediators of pain and distress. The type of tool used therefore will depend on the question being asked, be it defining an "at-risk" personality, where the Big 5 could be used, or examining a "cluster of behaviors", where the Temperament and Character Inventory could be helpful.

Thus certain personality styles may more directly link to the biology of fibromyalgia than the non-specific stress arousing "generic" personality styles. While recognizing that fibromyalgia and personality are complex we have shown through this review that they are linked. Further studies are required to better define the interaction of personality in fibromyalgia.

\section{ACKNOWLEDGEMENT}

Declared none.

\section{CONFLICT OF INTEREST}

The authors confirm that this article content has no conflict of interest.

\section{REFERENCES}

[1] Wolfe F, Ross K, Anderson J, Russell IJ, Hebert L. The prevalence and characteristics of fibromyalgia in the general population. Arthritis Rheum 1995; 38: 19-28.

[2] Wolfe F, Smythe HA, Yunus MB, et al. The American College of Rheumatology 1990 Criteria for the Classification of Fibromyalgia. Report of the Multicenter Criteria Committee. Arthritis Rheum 1990; 33: 160-72.

[3] Wolfe F. Fibromyalgia. Rheum Dis Clin North Am 1990; 16: 68198.

[4] Ardic F, Toraman F. Psychological dimensions of pain in patients with rheumatoid arthritis, fibromyalgia, syndrome and chronic low back pain. J Musculoskelet Pain 2002; 10: 19-29.

[5] Herken H, Gursoy S, Yetkin O, Virit O, Esgi K. Personality characteristics and depression levels in female patients with fibromyalgia syndrome. Int Med J 2001; 8: 41-4.

[6] Amir M, Neuman L, Bor O, Shir Y, Rubinow A, Buskila D. Coping styles, Anger, Social Support, and Suicide Risk of Women with Fibromyalgia. J Musculoskelet Pain 2000; 8: 7-20.

[7] Asbring P, Narvanen AL. Ideal versus reality: physicians perspectives on patients with chronic fatigue syndrome (CFS) and fibromyalgia. Soc Sci Med 2003; 57: 711-20.
[8] Shoda Y, Mischel W, Wrigth. Intraindividual stability in the organization and patterning behavior: incorporating psychological situations into the idiographic analysis of personality, personality processes and individual difference. J Pers Soc Psychol 1994; 67: 674-87.

[9] Johannsson V. Does a Fibromyalgia Personality Exist? J Musculoskelet Pain 1993; 1: 245-52.

[10] Ferrari R. The biopsychosocial model--a tool for rheumatologists. Bailliere Best Pract Res Clin Rheumatol 2000; 14: 787-95.

[11] Clauw DJ. The pathogenesis of chronic pain and fatigue syndromes, with special reference to fibromyalgia. Med Hypotheses 1995; 44: 369-78.

[12] Wolfe F, Clauw DJ, Fitzcharles MA, et al. The American College of Rheumatology preliminary diagnostic criteria for fibromyalgia and measurement of symptom severity. Arthrit Care Res 2010; 62: 600-10.

[13] Yunus MB, Ahles TA, Aldag JC, Masi AT. Relationship of clinical features with psychological status in primary fibromyalgia. Arthritis Rheum 1991; 34: 15-21.

[14] Herken H, Gursoy S, Yetkin OE, Virit O, Esgi K. personality characteristics and depression level of the female patients with fibromyalgia syndrome. Int Med J 2001; 8: 41-4.

[15] Cymet TC. A practical approach to fibromyalgia. J Natl Med Assoc 2003; 95: 278-85.

[16] Ekselius L, Bengtsson A, von Knorring L. Personality traits as determined by means of the Karolinska Scales of Personality in patients with fibromyalgia. J Musculoskelet Pain 1998; 6: 35 -49.

[17] Gursoy S, Erdal E, Herken H, Madenci E, Alasehirli B. Association of $\mathrm{T} 102 \mathrm{C}$ polymorphism of the 5-HT2A receptor gene with psychiatric status in fibromyalgia syndrome. Rheumatol Int 2001; 21: 58-61.

[18] Magnusson AE, Nias D, White P. Is perfectionism associated with fatigue? J Psychosom Res 1996; 41: 377-83.

[19] Soderberg S, Lundman B, Norberg A. Living with fibromyalgia: sense of coherence, perception of well-being, and stress in daily life. Res Nurs Health 1997; 20: 495-503.

[20] Kendall SA, Elert J, Ekselius L, Gerdle B. Are perceived muscle tension, electromyographic hyperactivity and personality traits correlated in the fibromyalgia syndrome? J Rehabil Med 2002; 34 : 73-9.

[21] Smythe HA. Problems with the MMPI. J Rheumatol 1984; 11: 4178 .

[22] Diagnostic and statistical manual of mental disorders: DSM-IV-TR $4^{\text {th }}$ ed. Washington, DC: American Psychiatric Association 2000.

[23] Carlsson AM. Characteristics of patients with chronic pain in comparison with normal controls and depressed patients. Pain 1986; $25: 373-82$.

[24] Ardic F, Toraman F. Psychological dimensions of pain in patients with rheumatoid arthritis, fibromyalgia syndrome and chronic low back pain. J Musculoskelet Pain 2002; 10: 19-29.

[25] Yunus MB. Psychological aspects of fibromyalgia syndrome: a component of the dysfunctional spectrum syndrome. Bailliere Clin Rheum 1994; 8: 811-37.

[26] Vendrig AA. The Minnesota Multiphasic Personality Inventory and chronic pain: a conceptual analysis of a long standing but complicated relationship. Clin Psychol Rev 2000; 20: 533-59.

[27] Anderberg U, Forsgren T, Ekselius L, Marteinsdottir I, Hallman J. Personality traits on the basis of Temperament and Character Inventory in female fibromyalgia syndrome patients. Nord J Psychiatry 1999; 5: 353-359.

[28] Nordahl HM, Stiles TC. Personality styles in patients with fibromyalgia, major depression and healthy controls. Ann Gen Psychiatry 2007; 6: 9.

[29] Ahles TA, Yunus MB, Riley SD, Bradley JM, Masi AT. Psychological factors associated with primary fibromyalgia syndrome. Arthritis Rheum 1984; 27: 1101-6.

[30] Payne TC, Leavitt F, Garron DC, Katz RS, Golden HE, Glickman PB, Vanderplate C. Fibrositis and psychologic disturbance. Arthritis Rheum 1982; 25: 213-7.

[31] Gregory R, Manring J, Wade M. Personality traits related to chronic pain. Ann Clin Psychiatry 2005; 17: 213-7.

[32] Gerson A, Fox DD. Fibromyalgia revisited: Axis II factors in the MMPI and historical data in compensation claimants. Am J Forensic Psychol 2003; 21: 21-5.

[33] Trygg T, Lundberg G, Rosenlund E, Timpka T, Gerdle B. Personality characteristics of women with fibromyalgia and of 
women with chronic neck, shoulder, or low back complaints in terms of minnesota multiphasic personality inventory and defense mechanism technique modified. J Musculoskelet Pain 2002; 10: 33-55.

[34] Gerson A, Fox D. Fibromyalgia revisited: Axis II factors in the MMPI and historical data in compensation claimants. Am J Forensic Psychol 2003; 21: 21-5.

[35] Ahles TA, Yunus MB, Gaulier B, Riley SD, Masi AT. The use of contemporary MMPI norms in the study of chronic pain patients. Pain 1986; 24: 159-63.

[36] Holmlund U. Change and stability of needs from middle adolesence to young adulthood in Swedish females. Eur J Pers 1991; 5: 379-85.

[37] Ekselius L, Bengtsson A, von Knorring L. Personality traits as determined by means of the Karolinska Scales of Personality in patients with fibromyalgia. J Musculoskelet Pain 1998; 6: 35-49.

[38] Ortet G, Ibanez M, llerena A, Torrubia R. The underlying traits of the Karolinska Scales of Personality (KSP). Eur J Psychol Assess 2002; 18: 139-48.

[39] Oner O, Akin A, Herken H, et al. Association among SNAP-25 gene DdeI and MnlI polymorphisms and hemodynamic changes during methylphenidate use: a functional near-infrared spectroscopy study. J Atten Disord 2011; 15: 628-37.

[40] Anderberg UM, Forsgren T, Ekselius L, Marteindottir I, Hallman J. Personality traits on the basis of the temperament and character inventory in female fibromyalgia syndrome patients. Nord J Psychiatry 1999: 353-9.

[41] Griego J, Stewart SE, Coolidge FL. A convergent validity study of Cloninger's Temperament and Character Inventory with the Coolidge Axis II Inventory. J Pers Disord 1999; 13: 257-67.

[42] Conrad R, Schilling G, Bausch C. Temperament and character personality profiles and personality disorders in chronic pain. Pain 2007; 133: 197-209.

[43] Lundberg G, Anderberg U, Gerdle B. Personality factors in female fibromyalgia syndrome. J Musculoskelet Pain 2009; 17: 117-30.

[44] Lundberg G, UM A, Gerdle B. Personality Features in female fibromyalgia syndrome. J Musculoskelet Pain 2009; 17: 117-30.

[45] Cloninger R. A systematic method for clinical description and classification of personality variants. Arch Gen Psychiatry 1987; 44: 573-85.

[46] Hofmann S, Loh R. the tridimensional personality questionnaire: changes during psychological treatment of social phobia. J Psychiatr Res 2005; 40: 214-20.

[47] Wetzel R, Brown S, Horn SC, Knesevich M, Wolfe H, Cloninger R. Correlates of tridimensional personality questionnaire scales with selected minnesota multiphasic personality inventory scales. Psychol Rep 1992; 7 : 1027-38.

[48] Nixon SJ, Parsons OA. Cloninger's tridimensional theory of personality: construct validity in a sample of college students. Pers Indiv Differ 1989; 10: 1261-7.

[49] Smith T, Pope M, Rhodewalt F, Poulton J. Optimism, neuroticism, coping and symptom reports: an alternative interpretation of the life orientation test. J Pers Soc Sci 1989; 56: 640-8.

[50] Buskila D, Cohen H, Neumann L, Ebstein RP. An association between fibromyalgia and the dopamine D4 receptor exon III repeat polymorphism and relationship to novelty seeking personality traits. Mol Psychiatr 2004; 9: 730-1.

[51] Beck AT, Epstein N, Harrison R, Emer G. Development of the sociotropy-autonomy scale: a measure of personality factors in psychopathology. University of Pennsylvania: Philadelphia 1983.

[52] Costa PT, McCrae RR. NEO PI-R. Professional Manual. Florida: Psychological Assessment Resources Inc. 1985.

[53] Korotkov D, Hannah T. The five factor model of personality: strengths and limitations in predicting health status, sick role and illness behaviour. Pers Indiv Differ 2004; 36: 187-99.

[54] Buss D, Ed. Social adaptation and five major factors of personality. New York: The Guilford Press 1996.

[55] Watson D, Hubbard B. Adaptational style and disposition structure: coping in the context of the five factor model. J Pers 1996; 64: 73773.

[56] Watson D, Pennebaker J. Health complaints, stress and distress, exploring the central role of negative affectivity. Psychol Rev 1989; 96: 234-54.

[57] Asghari MA, Nicholas MK. Personality and adjustment to chronic pain. Pain Rev 1996; 6: 85-97.
[58] Kersh BC, Bradley LA, Alarcon GS, et al. Psychosocial and health status variables independently predict health care seeking in fibromyalgia. Arthritis Rheum 2001; 45: 362-71.

[59] Charles ST, Kato K, Gatz M, Perderson N. Physical health 25 years later: the predicitive ability of neuroticism. Health Psychol 2008; 27: 369-78.

[60] Netter P, Hennig J. The fibromyalgia syndrome as a manifestation of neuroticism? Z Rheumatol 1998; 57 (Suppl 2): 105-8.

[61] Raselli C, Broderick JE. The association of depression and neuroticism with pain reports: a comparison of momentary and recalled pain assessment. J Psychosom Res 2007; 62: 313-20.

[62] Eysenck H, Eysenck S. The manual for the Eysenck Personality Questionnaire. London: Hodder \& Stoughton 1975.

[63] Malt EA, Olafsson S, Lund A, Ursin H. Factors explaining variance in perceived pain in women with fibromyalgia. BMC Musculoskelet Disord 2002; 3: 12 .

[64] Van Houdenhove B, Neerinckx E, Onghena P, Lysens R, Vertommen H. Premorbid "overactive" lifestyle in chronic fatigue syndrome and fibromyalgia. An etiological factor or proof of good citizenship? J Psychosom Res 2001; 51: 571-6.

[65] Wolfe F, Cathey MA, Kleinheksel SM, et al. Psychological status in primary fibrositis and fibrositis associated with rheumatoid arthritis. J Rheumatol 1984; 11: 500-6.

[66] Rains JC, Penzien DB. Sleep and chronic pain: challenges to the alpha-EEG sleep pattern as a pain specific sleep anomaly. J Psychosom Res 2003; 54: 77-83.

[67] Blasco Claros L, Mallo CM, Mencia PA, et al. Clinical profiles in fibromyalgia patients of the community mental health center: a predictive index of psychopathological severity. Actas Esp Psiquiatri 2006; 34: 112-22.

[68] Johnson AL, Storzbach D, Binder LM, et al. MMPI-2 profiles: fibromyalgia patients compared to epileptic and non-epileptic seizure patients. Clin Neuropsychol 2010; 24: 220-34

[69] Johannsson V. Does a fibromyalgia personality exist? In: Jacobsen S, Danneskiold-Samoe B, Lund B, Eds. Musculoskeletal Pain, Myofascial Pain Syndrome and Fibromyalgia Syndrome. New York: The Haworth Press 1993; pp. 245-52.

[70] Panek PE, Skowronski JJ, Wagner EE. Differences on the projective hand test among chronic pain patients reporting three different pain experiences. J Pers Assess 2002; 79: 235-42.

[71] Ramirez-Maestre C, Lopez Martinez AE, Zarazaga RE. Personality characteristics as differential variables of the pain experience. $\mathrm{J}$ Behav Med 2004; 27: 147-65.

[72] Glazer Y, Buskila D, Cohen H, Ebstein RP, Neumann L. Differences in the personality profile of fibromyalgia patients and their relatives with and without fibromyalgia. Clin Exp Rheumatol 2010; 28: S27-32.

[73] Zautra AJ, Johnson LM, Davis MC. Positive affect as a source of resilience for women in chronic pain. J Consult Clin Psych 2005; 73: 212-20.

[74] Malin K, Littlejohn G. Neuroticism in young women with fibromyalgia links to key clinical features. Pain Treat Res 2012; 2012:730741.

[75] Verdejo-Garcia A, Lopez-Torrecillas F, Calandre EP, DelgadoRodriguez A, Bechara A. Executive function and decision-making in women with fibromyalgia. Arch Clin Neuropsychol : the official J Nat Acad Neuropsych 2009; 24: 113-22.

[76] Mazza M, Mazza O, Pomponi M, et al. What is the effect of selective serotonin reuptake inhibitors on temperament and character in patients with fibromyalgia? Compr Psychiatry 2009; 50: 240-4.

[77] Riva R, Mork PJ, Westgaard RH, Ro M, Lundberg U. Fibromyalgia syndrome is associated with hypocortisolism. Int $\mathrm{J}$ Behav Med 2010; 17: 223-33.

[78] Fishbain DA, Cole B, Cutler RB, Lewis J, Rosomoff HL, Rosomoff RS. Chronic pain and the measurement of personality: do states influence traits? Pain med 2006; 7: 509-29.

[79] Katon W, Sullivan M, Walker E. Medical symptoms without identified pathology: relationship to psychiatric disorders, childhood and adult trauma, and personality traits. Ann Intern Med 2001; 134: 917-25.

[80] Hauser W, Biewer W, Gesmann M, et al. A comparison of the clinical features of fibromyalgia syndrome in different settings. Eur J Pain 2011; 15(9): 936-41.

[81] Littlejohn G. Fibromyalgia. What is it and how do we treat it? Aust Fam Phys 2001; 30: 327-33. 
[82] Littlejohn GO, Walker J. A realistic approach to managing patients with fibromyalgia. Curr Rheumatol Rep 2002; 4: 286-92.

[83] Boisset-Pioro MH, Esdaile JM, Fitzcharles MA. Sexual and physical abuse in women with fibromyalgia syndrome. Arthritis Rheum 1995; 38: 235-41.

[84] Weissbecker I, Floyd A, Dedert E, Salmon P, Sephton S. Childhood trauma and diurnal cortisol disruption in fibromyalgia syndrome. Psychoneuroendocrinology 2006; 31:312-24.

[85] Raphael KG, Natelson BH, Janal MN, Nayak S. A communitybased survey of fibromyalgia-like pain complaints following the World Trade Center terrorist attacks. Pain 2002; 100: 131-9.

[86] Cohen H, Neumann L, Haiman Y, Matar MA, Press J, Buskila D. Prevalence of post-traumatic stress disorder in fibromyalgia patients: overlapping syndromes or post-traumatic fibromyalgia syndrome? Semin Arthritis Rheum 2002; 32: 38-50.

[87] Walen HR, Oliver K, Groessl E, Cronan PA, rodriguez MV. Traumatic events, health outcomes, and health care use in patietns with Fibromyalgia. J Musculoskelet Pain 2001; 9: 19-38.

[88] Hudson JI, Pope HG Jr. The relationship between fibromyalgia and major depressive disorder. Rheum Dis Clin North Am 1996; 22: 285-303.

[89] Trygg T, Lundberg G, Rosenlund E, Timpka T, Gerdle B. Personality characteristics of women with fibromyalgia and of women with chronic neck, shoulder, or low back complaints in terms of Minnesota Multiphasic Personality Inventory and Defense Mechanism Technique modified. J Musculoskelet Pain 2002; 10: 33-55.

[90] Rains JC, Penzien DB. Sleep and chronic pain: challenges to the alpha-EEG sleep pattern as a pain specific sleep anomaly. [see comment]. J Psychosom Res 2003; 54: 77-83.

[91] Harding SM. Sleep in fibromyalgia patients: subjective and objective findings. Am J Med Sci 1998; 315: 367-76.

[92] Friedberg F, Jason LA. Chronic fatigue syndrome and fibromyalgia: clinical assessment and treatment. J Clin Psychol 2001; 57: 433-55.
[93] Wolfe F, Ross K, Anderson J, Russell IJ, Hebert L. The prevalence and characteristics of fibromyalgia in the general population. Arthritis Rheum 1995; 38: 19-28.

[94] Gursoy S, Erdal E, Herken H, Madenci E, Alasehirli B. Association of T102C polymorphism of the 5-HT2A receptor gene with psychiatric status in fibromyalgia syndrome. Rheumatol Int 2001; 21: 58-61.

[95] Larson RJ, Buss DM, Eds. Personality Psychology: Domains of Knowledge about Human Nature. USA: McGraw Hill 2005.

[96] Mayer J. Structural Divisions of Personality and Classification of Traits. Rev Gen Psychol 2003; 7: 381-401.

[97] McAdams DP, Pals JL. A new big five: Fundamental principles for an intergrative science of personality. Am Psychol 2006; 61: 20417.

[98] Johannsson V. Does a Fibromyalgia personality Exist? J Musculoskelet Pain 1993; 1: 254-2.

[99] Svrakic D, Przybeck T, Cloninger R. Mood states and personality traits. J Affect Disord 1992: 217-26.

[100] Zautra AJ, Hamilton NA, Burke HM. Comparison of stress responses in women with two types of chronic pain: fibromyalgia and osteoarthritis. Cogn Ther Res 1999; 23: 209-30.

[101] Carlsson A. Personality characteristics of patients with chronic pain in comparison with normal controls nand depressed patients. Pain 1986: 373-82.

[102] Littlejohn GO. Balanced treatments for fibromyalgia. Arthritis Rheum 2004; 50: 2725-9.

[103] Littlejohn GO, Guymer EK. Fibromyalgia syndrome: which antidepressant drug should we choose. Curr Pharm Des 2006; 12: 3-9.

[104] Payne TC, Leavitt F, Garron DC, et al. Fibrositis and psychologic disturbance. Arthritis Rheum 1982; 25: 213-7.

[105] Asghari MA, Nicholas MK. Personality and adjustment to chronic pain. Pain Rev 1996; 6: 85-97.

(C) Malin and Littlejohn; Licensee Bentham Open.

This is an open access article licensed under the terms of the Creative Commons Attribution Non-Commercial License (http:/creativecommons.org/licenses/by-nc/ 3.0/) which permits unrestricted, non-commercial use, distribution and reproduction in any medium, provided the work is properly cited 